\title{
More Education, Better Jobs? A Critical Review of CCTs and Brazil's Bolsa Família Programme for Long-Term Poverty Reduction
}

\author{
Hayley Jones \\ Department of International Development, University of Oxford \\ E-mail: hayley.jones@qeh.ox.ac.uk
}

Conditional cash transfers have come to play a prominent role in the social policy landscape in Latin America and especially in Brazil in recent years. Evaluations of their impacts, however, have focused on limited short-term outcomes, particularly consumption and school enrolment and attendance rates. Long-term outcomes have received comparatively little attention. This article reviews the existing evidence on the long-term impacts of CCTS, focusing on the underlying assumptions in the CCT model for intergenerational poverty reduction. In doing so, it questions the notion that CCTs can indeed interrupt the intergenerational cycle of poverty through human capital investments that are thought to lead to expanded opportunities in the labour market. Moreover, it highlights the need for more research on the social processes that may influence young beneficiaries' life trajectories and experiences in poverty.

Key words: Conditional cash transfers, Bolsa Família, long-term impacts, intergenerational poverty.

\section{Introduction}

One of the most influential trends in social policy in Latin America in recent decades has been the emergence of conditional cash transfer (CCT) programmes, whereby poor households receive cash payments from the state on the condition that they fulfil established education- and health-related targets, such as minimum school attendance rates (Fiszbein and Schady, 2009; Barrientos and Nino-Zarazua, 2011). CCT programmes have two explicit objectives: (a) in the short-term, to provide immediate poverty alleviation by increasing basic consumption among the poor; and (b) in the long term, to increase human capital formation among poor children in order to break the intergenerational cycle of poverty.

With the rapid proliferation of CCT programmes across Latin America, there has been considerable effort to evaluate their impacts. Given their relatively recent implementation, evaluations and impact assessments have been limited mostly to the impacts on consumption with regard to CCTs' short-term aims, and to measures of school enrolment and attendance with regard to the programmes' long-term goal of human capital formation.

This article reviews the existing evidence on the long-term impacts of CCTs with education-related conditionalities, focusing on the underlying assumptions in the CCT model. In doing so, it questions the notion that CCTs can indeed interrupt the 
intergenerational cycle of poverty through human capital investments that are thought to lead to expanded opportunities in the labour market. Moreover, it highlights the need for more research on the social processes that may influence young beneficiaries' life trajectories and experiences of poverty.

The following section discusses the theoretical underpinnings and inherent assumptions of the CCT model for long-term, intergenerational poverty reduction. Based on this model, the third section reviews the existing empirical evidence from Brazil on the potential the Bolsa Família programme holds to facilitate long-term poverty reduction. Brazil's Bolsa Família is one of the first and largest CCTs globally, and has served as an example for many other similar programmes around the world. In many ways, then, it is a paradigmatic case with which to examine CCTs' long-term impacts. The review of the empirical evidence from Brazil highlights the gaps in our knowledge of the underlying assumptions and mechanisms in the CCT model key to understanding the long-term impacts and outcomes for young beneficiaries. Yet, this may not be sufficient to understanding CCTs' and the BFP's capacity for long-term poverty reduction. Drawing on the literature on young people's trajectories and transitions, the fourth section critiques the linearity of the CCT model for long-term poverty reduction, arguing that the CCT model and literature have failed to account for the complexity of young people's lives and trajectories through and out of poverty. The article concludes by suggesting that (a) the framework for long-term poverty reduction in CCTs appears to be at odds with much of the empirical evidence and of what we know of young people's trajectories; and (b) we need much more research on the social processes that shape young people's trajectories in understanding these programmes' potential for long-term, intergenerational poverty reduction.

\section{The CCT model for long-term poverty reduction}

CCTs are based on a particular understanding of poverty; that is, that poor households face individual constraints, such as low levels of physical assets and education (human capital) (Roelen, 2014), resource constraints that may limit their ability to invest in these and/or misinformation about the returns to investments (such as in education) (Fiszbein and Schady, 2009). Low levels of human capital and constraints on investing in children's human capital thus prevent many poor households from escaping poverty across generations. CCTs seek to address this deficit in human capital investment among the poor by providing the resources (cash) and the incentives (education conditionalities) to facilitate human capital development among poor children, which will allow them to lift themselves and their families out of poverty over the long term (Roelen, 2014).

The reproduction of poverty across generations is therefore understood to stem from a lack of investment in human capital, particularly in the area of education, which 'leads to low worker productivity and depressed incomes in the future' (Lomelí, 2008: 479). Conditionality is meant to ensure that households make 'efficient educational decisions' (Lomelí, 2008: 479), which will boost human capital stock in poor households, which will in turn increase productivity and incomes and expand labour market opportunities (Lomelí, 2008). CCTs thus link the intergenerational transmission of poverty to a lack of human capital and in turn poor labour market opportunities and thus outcomes. The implicit logic of the programmes' structure and long-term aims is illustrated in Figure 1. 


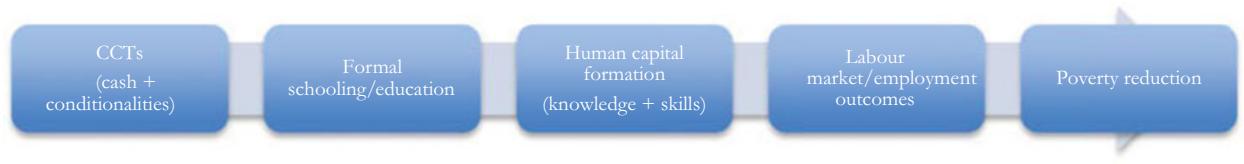

Figure 1. (Colour online) The CCT model for long-term poverty reduction

Through conditionality attached to the receipt of the cash transfer, CCTs require the uptake of education on the assumption that increased access to formal schooling will lead young beneficiaries to acquire the human capital (that is, knowledge and skills) required to improve employment outcomes in the labour market upon completion of compulsory schooling; that is the 'wage implications of marginally better schooling supposedly kick in' (Saad-Filho, 2015: 1237), strengthening 'recipients' position in the labour market' (Saad-Filho, 2015: 1231). In turn, enhanced future productivity and earnings for young beneficiaries as they move into adulthood (Lomelí, 2008) will allow them to lift themselves and their families out of poverty, breaking the intergenerational cycle of poverty.

\section{Linking schooling and human capital formation}

Conditionality in CCTs explicitly links schooling and human capital formation (see, for instance, Lindert et al., 2007; Fiszbein and Schady, 2009; Soares, 2012; Digilova et al., 2014; Saad-Filho, 2015). CCTs are understood to reduce poverty over the long term by increasing young beneficiaries' human capital, which is ensured by conditions related to young people's school enrolment and attendance. Unsurprisingly, given conditionalities related to school enrolment and attendance, much of the evidence to support the link between CCTs and human capital formation has come in the form of econometric analyses of behavioural change, specifically of the impacts of school enrolment and attendance, or, the 'quantity' of schooling received by young beneficiaries. Based on observed increases in school enrolment and attendance rates, CCTs are presumed to be facilitating human capital formation among young beneficiaries.

Yet, access to (or quantity of) schooling does not guarantee learning (Hanushek, 2009). In linking schooling to human capital formation through educational conditionalities, the CCT model makes inherent assumptions about the quality of that schooling - that is, what is being accessed and what capabilities and competencies, or skills, are being acquired (CREATE, 2008). The model takes for granted that the quality of schooling that young beneficiaries access is of sufficient quality to provide the required human capital (alternatively, knowledge and skills) to increase their future productivity and incomes in the labour market. Understanding the long-term impact of CCTs on poverty reduction requires moving beyond the programmes' ability to increase school enrolment and attendance rates to incorporate notions of educational quality and outcomes.

Despite the underlying assumptions in the CCT model about the quality of schooling received by young beneficiaries, the academic and policy literature on CCTs has largely ignored the notion of quality in education. This may be at least partly explained by the difficulties in establishing what constitutes 'quality' in education. There is an extensive literature on educational quality, with a variety of ways of operationalising 'quality' (Leu, 2005; Tawil et al., 2012) in an attempt to identify the elements of quality that 
policy can address. A common approach in both the academic and policy literature has been through an 'input-process-output' approach that looks at school characteristics that impact learning, achievement and experiences at school. This approach seeks to measure 'inputs', such as teaching and learning materials, physical infrastructure, and teacher quality, and then to measure educational 'outputs', usually in the form of student achievement on standardised assessments (Leu, 2005; Tawil et al., 2012).

While many proxy indicators have tended to be used for quality in education, increasing attention has been given to the idea of cognitive skills acquisition among students as a measure of quality of education systems and educational outputs. The focus on cognitive skills has been exemplified in the implementation of many international assessments, such as the Programme for International Student Assessment (PISA), that aim to test cognitive achievement.

In sum, the CCT model makes inherent assumptions about the quantity and quality of schooling received by young beneficiaries - specifically, that the quantity and the quality of their schooling will be sufficient to lead to human capital acquisition, which will in turn improve their employment outcomes in the labour market. Thus far, the CCT literature and empirical evidence has been limited to measures of school enrolment and attendance. In order to understand the link between schooling and human capital in the context of CCTs, there is a need to expand the empirical evidence on schooling to incorporate notions of quality and learning in schooling. Indeed, as the third section shows, the empirical evidence on quality of schooling in Brazil suggests that the link between schooling and human capital formation should not be taken for granted.

\section{Linking human capital formation and employment}

The CCT model makes a crucial link between poverty and a lack of schooling/human capital. In order to have the desired long-term impact on poverty, however, higher rates of school attendance must not only translate into enhanced human capital formation among beneficiaries, but also into better jobs that will enable young people to improve their income generation capacity and move out of poverty. Indeed, the rationale for conditionality in CCTs is to guarantee human capital development among children in beneficiary households in order to enhance their earning potential and therefore make them more likely to escape the intergenerational transmission of poverty (Digilova et al., 2014).

The CCT model thus draws on human capital theory in linking schooling and human capital to employment outcomes, and is the basis of CCTs aim to reduce longterm poverty; that is, increased human capital among young beneficiaries is meant to increase their future productivity and earnings in the labour market. Human capital theory similarly maintains that schooling contributes to the development of human capital, which determines access to employment (Davis and Moore, 1945; Mincer, 1958; Becker, 1962; Becker and Chiswick, 1966). In essence, education is the mechanism through which individuals acquire the skills required by the labour market, and labour market outcomes (that is, jobs and earnings) are proportional to individuals' human capital endowments. Human capital theory can be understood as illustrated in Figure 2.

While human capital theory may be central to the logic and design of CCTs, we have reason to question its validity in the context of many Latin American countries - and other developing countries as well. Based on insights from the dualistic theories (see, for 


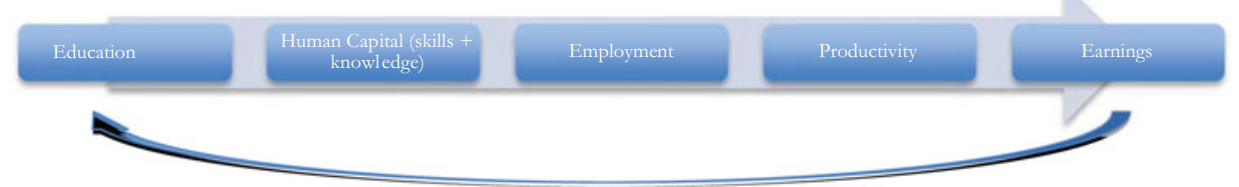

Figure 2. (Colour online) The relationship between education and earnings in human capital theory

instance, Collins, 1971, 1979; Phelps, 1972), we know that processes of discrimination and segmentation in the labour market may shape access to employment along the lines of, for example, ethnicity, gender, informal/formal sectors. At the same time, social capital theories suggest that social networks may shape access to the labour market (Granovetter, 1974; Lin, 1999; Mouw, 2003). The linearity of the CCT model, which sees employment outcomes as directly related to human capital stocks, discounts such social processes and factors that may shape access to labour markets for young beneficiaries.

The linearity of the CCT model also fails to account for the demand side of the employment equation; that is, what jobs will be available in the labour market, what returns to schooling and human capital those jobs will offer, and to what extent these returns are commensurate with facilitating long-term poverty reduction. As the third section highlights, in Brazil there is evidence to suggest that these other possible factors, which shape access, availability and returns to employment, may influence young beneficiaries' employment and in turn poverty outcomes, calling into question the linearity of the CCT model.

\section{The empirical evidence on CCTs: what we know and what we still need to know}

With the rapid expansion of the Bolsa Família programme as a key tool of social protection in Brazil, there has been a considerable effort to evaluate its impacts. Given its relatively recent implementation, evaluations and impact assessments have been limited mostly to measures of consumption, school enrolment and attendance, and rates of vaccination and attendance at health centres (Bourguignon et al., 2002, 2003; Resende and Oliveira, 2008). The long-term impacts of the BFP on poverty, particularly with regard to young beneficiaries' long-term trajectories and outcomes in schooling and the labour market, have received comparatively little attention. ${ }^{1}$ This section examines the empirical evidence from both the secondary literature and government data, highlighting the gaps in our knowledge of CCTs longer term impacts.

\section{Brazil's Bolsa Família}

One of the first and largest CCT programmes globally is Brazil's Bolsa Família programme (BFP), which now covers about one-quarter of the country's population and has inspired many similar programmes in other developing countries (Saad-Filho, 2015). The programme was originally introduced at the municipal level in the cities of Campinas and Brasília in 1995, subsequently scaled up to the national level in 2001 under the name Bolsa Escola,${ }^{2}$ and then amalgamated with other cash transfer programmes into the 
Table 1 Bolsa Família conditional cash transfer benefit structure

\begin{tabular}{|c|c|c|c|}
\hline Benefit & Criteria & $\begin{array}{l}\text { Households with a per capita } \\
\text { monthly income of up to } \\
\mathrm{R} \$ 154.00)^{\mathrm{a}}\end{array}$ & Conditionalities \\
\hline $\begin{array}{l}\text { Child } \\
\text { benefit }\end{array}$ & $\begin{array}{l}\text { Households } \\
\text { with children } \\
\text { and young } \\
\text { people aged } \\
6-15 \text { years }\end{array}$ & $\begin{array}{l}\text { Transfer of } \mathrm{R} \$ 35.00^{\mathrm{b}} \text { per } \\
\text { month per person meeting } \\
\text { criteria up to five people per } \\
\text { household }\end{array}$ & $\begin{array}{l}\text { Conditionalities: } 85 \% \\
\text { school attendance rate } \\
\text { each month; children } \\
\text { under the age of } 7 \text { receive } \\
\text { recommended } \\
\text { vaccinations and attend } \\
\text { regular health check ups }\end{array}$ \\
\hline $\begin{array}{l}\text { Adolescent } \\
\text { benefit }\end{array}$ & $\begin{array}{l}\text { Households } \\
\text { with young } \\
\text { people aged } \\
16-17 \text { years }\end{array}$ & $\begin{array}{l}\text { Transfer of } \mathrm{R} \$ 42.00^{\mathrm{C}} \text { per } \\
\text { month per person meeting } \\
\text { criteria up to two people per } \\
\text { household }\end{array}$ & $\begin{array}{l}\text { Conditionalities: } 75 \% \\
\text { school attendance rate } \\
\text { each month }\end{array}$ \\
\hline
\end{tabular}

Notes: ${ }^{\text {a }}$ Approx. USD $\$ 20.00$.

${ }^{\mathrm{b}}$ Approx. USD \$9.00.

cApprox. USD \$11.00.

Source: Compiled by author with information from the Ministério de Desenvolvimento Social e Combate à Fome (MDS) (2015).

Bolsa Família programme in 2003. Since then, the programme has become the flagship programme of the government's social policy architecture.

The programme offers both fixed and variable benefits, which, under certain circumstances, are conditional or unconditional. The largest and most well-known component of the programme is the benefit conditional on school enrolment and attendance, requiring a minimum of 85 per cent school attendance for children aged six to fifteen years old, and 75 per cent for young people aged sixteen to seventeen. While conditionalities in the BFP have traditionally been considered 'softer' in their implementation than in some other programmes, such as Mexico's Oportunidades programme, the enforcement of conditionalities has become increasingly strict (Soares, 2012). Table 1 shows the benefit structure of the components with education-related conditionalities as of late 2015.

\section{Schooling and human capital formation}

CCTs aim to contribute to building human capital among the poor with conditionalities attached to schooling, based on the strong established correlation between schooling and future economic wellbeing through increased labour productivity and income. The empirical evidence on the BFP supports a positive impact on enrolment and attendance rates, particularly at the secondary level (see, for example, Bourguignon et al., 2002, 2003; CEDEPLAR, 2005; Soares et al., 2010). Silveira Neto (2010) estimates a 2 and 3 per cent increase in school attendance and enrolment, respectively, as a result of the programme. On the other hand, the impact on grade promotion remains ambiguous (see, for example, CEDEPLAR, 2005; Glewwe and Kassouf, 2012; Fiszbein and Schady, 2009; Soares et al., 2010). Perhaps most importantly, however, the impact on achievement 
Table 2 Brazil - average PISA scores

\begin{tabular}{llllll}
\hline \hline & PISA 2000 & PISA 2003 & PISA 2006 & PISA 2009 & PISA 2012 \\
\hline Reading & \multirow{2}{*}{396} & 403 & 393 & 412 & 410 \\
Mathematics & & 356 & 370 & 386 & 391 \\
Science & & 390 & 405 & 405 \\
\hline \hline
\end{tabular}

Source: OECD (2010, 2012).

and learning is not at all clear. In a study of Bolsa Família beneficiary children in São Paulo state, Santarrosa (2011) estimates no significant effect on cognitive development and academic achievement. Overall, the empirical evidence suggests that CCTs have had a positive impact on the uptake of educational services; yet, the extent to which young beneficiaries are accessing schooling of sufficient quality and are acquiring the human capital envisioned by the BFP is far from clear. Indeed, Brazil's results in national and international assessments of learning appear to reflect poor quality schooling and educational outcomes that may not be consistent with the human capital formation foreseen in the CCT model. Since 2000, Brazil has participated in PISA, which assesses the performance of fifteen-year olds in literacy, mathematics and science. Brazil's average PISA scores improved considerably between 2000 and 2012, from 396 to 410 in reading, from 356 to 391 in mathematics and from 390 to 405 in science (OECD, 2010, 2012) (see Table 2). These gains represent the third largest improvement on record for PISA (Bruns et al., 2012).

Despite these gains, Brazil remains one of the lowest performing countries included in the PISA. Within the LAC region, Chile, Uruguay and Mexico all perform better than Brazil, and the gap in maths skills between the average Chinese student (in Shanghai) and the average Brazilian student amounts to approximately five years of schooling (Bruns et al., 2012). Moreover, nearly half (49.2 per cent) of Brazilian students performed below the baseline level of proficiency in 2012, along with 67.1 per cent in mathematics and 61 per cent in science (OECD, 2012). This implies that a majority of fifteen-year olds lack basic life skills that could potentially limit their ability to continue studying or to obtain a good job.

While there has been no clear trend in PISA reading scores, the share of students lacking basic literacy skills remained essentially unchanged between 2003 and 2009 at 50 per cent, with the share of 'high performers' representing a mere 1.3 per cent even in 2009 (Bruns et al., 2012). An estimated 60 per cent of students scored below the 'low performance' threshold of 400 in mathematics on the 2009 PISA, meaning that they lack basic numeracy skills (Bruns et al., 2012); this compares to an average of 14 per cent in OECD countries and between 3 and 5 per cent in top performing countries (Bruns et al., 2012). Moreover, the improvements in the PISA scores appear to be more a reflection of students reaching the appropriate grade on time rather than a closing of the gap with OECD learning levels (Bruns et al., 2012). These poor PISA scores, combined with the fact that by the end of secondary school a majority of students in Brazil do not meet the expected learning outcomes for the end of basic education established by the Brazilian government (PREAL, 2009), call into question the extent to which schooling is indeed facilitating human capital development among young beneficiaries. 
In terms of key inputs for cognitive skills and learning identified in the input-processoutput approach discussed above, Brazil faces a variety of challenges. In recent years, there has been a considerable increase in resources allocated to education, with spending expanding from 4 per cent of GDP in 2000 to 5.2 per cent in 2009 (OECD, 2010); however, it remains highly skewed in favour of tertiary over basic education (PREAL, 2009). Moreover, despite recent efforts to ensure more equitable distribution of federal education funding through the FUNDEF and FUNDEB programmes, spending remains highly unequal across states and regions, reflecting vastly differing capacities to support quality schooling.

Overall, while the BFP has had a positive impact on school enrolment and attendance rates among young beneficiaries, it is questionable as to whether these young beneficiaries are attending sufficiently high quality schools, and whether they are achieving the educational outcomes that would be required to change longer term trajectories and outcomes in the CCT model.

\section{Human capital and employment}

As argued in the second section, the CCT model links human capital formation among young beneficiaries to changed longer term employment outcomes. Thus far, there has been very limited research on labour market integration as a result of CCTs, and this has focused on disincentives to labour participation among caregivers rather than on young beneficiaries' employment outcomes. Drawing on the theoretical literature discussed above, the empirical evidence on access, availability and returns to employment suggest that the linearity of the CCT model may not hold for young beneficiaries.

There is considerable evidence from Brazil that the linearity of the relationship between human capital stocks and employment may not hold. Drawing on dualistic theories, there is ample evidence linking race and gender to low income and low labour mobility, with the most affected groups including non-whites and women (Lovell, 2003, 2006; Arias et al., 2004; Loureiro et al., 2004; Ferreira and Veloso, 2006; Marió et al., 2008; Menezes-Filho and Scorzafave, 2009; Saboia and Saboia, 2009; Arbache and Loureiro, 2012; Fontes et al., 2012; Cacciamali and Tatei, 2013). Lower wages and higher rates of informality in the labour market both contribute to the disproportionate representation of non-whites among the poor with limited income and labour mobility (Arcand and D'Hombres, 2004; Arias et al., 2004), with non-white Brazilians earning about half the wages of white Brazilians (Saboia and Saboia, 2009).

In terms of availability of employment in the labour market, there is evidence to support a considerable degree of structural heterogeneity, which may limit young beneficiaries' ability to access jobs upon leaving the BFP. The large proportion of low productivity employment is highly concentrated among the lower income quintiles (CEPAL, 2012), limiting the availability of jobs (and good quality jobs) to the poor. Thus, relatively pronounced structural heterogeneity may be an important factor influencing the economy's capacity to create a sufficient number of jobs, and of good quality jobs, for the poor, particularly those exiting the BFP.

In addition, the empirical evidence of returns to employment in Brazil also appears problematic in terms of the link between human capital, employment and poverty reduction in the CCT model. With the expansion of public education and CCTs, educational attainment among the Brazilian labour force has steadily increased, 
with a growing proportion of the workforce now having completed secondary school (see, for example, Arabsheibani et al., 2006; Menezes-Filho and Scorzafave, 2009; Zepeda et al., 2009; Manacorda et al., 2010; Küpfer et al., 2012). As a result, the relative wages of semi-skilled/secondary-educated workers have fallen compared with both unskilled/primary and high-skilled/tertiary-educated workers (Giovannetti and Menezes-Filho, 2006; Manacorda et al., 2010). Thus, the dramatic expansion of semiskilled/secondary-educated workers has not been met with a parallel expansion in demand, leading to their diminishing wage/skills premium, and increasing levels of unemployment and informality (Menezes-Filho and Scorzafave, 2009). Ultimately, the wage/skills premium offered for intermediate to secondary education is fundamental to the CCT model, in terms of employment and long-term poverty reduction. If young beneficiaries see no gains in earnings attached to the additional schooling acquired as a result of the programme, it is unlikely that the cycle of intergenerational poverty will be broken.

In sum, the empirical evidence thus far suggests that (a) young beneficiaries' labour market incorporation may be weak, and (b) social processes beyond human capital stocks may shape young beneficiaries' long-term trajectories and outcomes in the labour market.

\section{Questioning the CCT model}

As the previous sections have argued, CCTs are understood to 'break the cycle of poverty by ensuring that the family's children are educated and have better prospects for the future' (Marshall and Hill, 2015: 743). Yet, at the broadest level, the linearity of the CCT model for intergenerational poverty reduction may be fundamentally problematic to the extent that it ignores the complexity of young beneficiaries' life trajectories.

The CCT model (illustrated in Figure 1) echoes much of the academic and policy literature based on a linear 'life stages' model (see Wyn and Dwyer, 2000; Moore, 2005; Camfield, 2011; Boyden and Dercon, 2012) that reflects broader global tendencies to frame 'successful' childhoods and 'transitions to adulthood' on the assumption of the successful completion of compulsory schooling and entry into the labour market. Much of this literature frames young people in terms of a progression over the lifecourse through sequential stages based on age and social life (for example, from childhood, to youth, to adulthood; from school to work). Thus, schooling and work are viewed as the 'main means of transitioning to a materially successful adulthood' (Camfield, 2011: 670). According to the logic of CCTs and the human capital model that underpins it, young beneficiaries move in a linear direction through schooling, ${ }^{3}$ after which they enter the labour market ${ }^{4}$ with greater skills and capacity to secure better livelihoods.

Yet, young people's schooling and labour market trajectories and transitions towards adulthood, particularly in situations of poverty, rarely reflect a linear developmental path (Camfield, 2011). Indeed, despite the Western model of youth that permeates the policy literature, there is a growing body of academic literature that problematises youth transitions, especially but not exclusively in the context of poverty (for instance, see Punch, 2002; Thompson, 2002; Jeffrey and McDowell, 2004; Jeffrey and Dyson, 2008; Morrow, 2013). Some authors have questioned the value of the concept of 'transitions' in that it suggests false binaries - between child and adult, school and work - and assumes a linear progression from one life stage to the next (Morrow, 2013). Others have suggested that concepts such as 'critical moments' (Thompson, 2002) and 'vital conjunctures' (Jeffrey, 
2010) may be more useful, as these account for the uneven and sometimes contradictory challenges that young people face in their lives (Camfield, 2011), while still others have offered concepts, such as 'social navigations' (Vigh, 2009), to explore how young people manage these challenges.

Overall, there is now widespread critique of the linearity of such 'life stages' models that fail to account for the diversity of young people's experiences in schooling, the labour market and other settings, and are often 'not sequenced in any predictable manner or in the way in which classic western models of growing up might lead us to expect' (Jeffrey, 2011: 793). For instance, Punch (2002) has shown that young people's school-to-work transitions may be influenced by a range of interconnected factors, including locality, economic resources, parental and individual attitudes, gender and social norms (such as those related to birth order) and social relations (such as networks). This is likely also the case in Brazil, and there is empirical evidence that suggests that such factors may play a crucial role in shaping young people's schooling, work and life trajectories. Taking the example of gender, for instance, there is considerable evidence of both the high prevalence of early pregnancy in Brazil (see World Bank, 2015) and its association with early school leaving (Almeida and Aquino, 2009). Yet, the CCT model and the academic and policy literature that supports it have yet to acknowledge the extensive literature and evidence contradicting the linearity of life stages models and the complexity of young people's trajectories and life experiences.

Furthermore, there is an extensive literature on the complexity of the intergenerational transmission of poverty that highlights the multitude of factors involved, from economic, to political, environmental and social (see, for instance, Harper and Marcus, 2003; Moore, 2005). Yet, the human capital and CCT model fails to account for this complexity and the range of factors - such as social relations (family, kin or household structures), social norms and practices (for example, shaping access to assets and the distribution of these within and between generations) and social networks (for example, shaping access to opportunities and resources) - that play a key role in shaping not only young people's trajectories across the lifecourse (Jeffrey and McDowell, 2004) but also the transmission of poverty across generations.

In sum, the extensive literature on young people's trajectories and transitions and the intergenerational transmission of poverty indicates that the process of long-term poverty reduction is much more complex than the human capital 'life stages' model at the heart of CCTs suggests. Young people may not move through school and the labour market in the linear fashion imagined by CCTs. Movement in and out of school and/or the labour market may mark many young people's lives in a more complex way and over a much more extended period of time than the CCT model considers. This may imply that CCTs' benefit structure and conditionalities - particularly in terms of the age and schooling requirements - and the logic of poverty reduction may be at odds with young people's trajectories and the social processes shaping these.

\section{Conclusions and Implications}

The CCT model for long-term poverty reduction is premised on the expansion of access to schooling, on the basis that increased human capital formation as a result of this schooling will ensure better labour market incorporation among young beneficiaries. This linear process - of schooling leading to human capital formation leading to better employment - 
is intended ultimately to lead to long-term, intergenerational poverty reduction. This article has attempted to unpick the underlying assumptions inherent in this model, highlighting the need for more consideration of these assumptions in the CCT literature and evaluations - from educational quality and outcomes, to possible factors beyond human capital mediating access, availability and returns to employment - particularly when thinking about long-term impacts and outcomes.

Based on the CCT model for long-term poverty reduction, this article then reviewed the existing empirical evidence from Brazil and the Bolsa Família programme. The evidence reviewed here suggests that (a) young beneficiaries may be enrolling and attending school at an increased rate as a result of the BFP, but it is not clear that the quality of the schooling they receive and the educational outcomes they achieve are commensurate with much human capital formation; and (b) young beneficiaries' labour market incorporation may be weak due to a variety of factors beyond human capital stocks. This evidence calls into question some of the inherent assumptions in the CCT model for long-term poverty reduction.

This article highlights the need for research on CCTs to incorporate the model's underlying assumptions in order to understand the extent to which it may or may not be conducive to long-term poverty reduction. At the same time, it also points to more fundamental questions about the model itself, specifically that the linearity of the CCT model has so far failed to acknowledge the complexities of young people's trajectories and life experiences as well as of the complexities of the process of intergenerational poverty reduction. The CCT model stands much to gain from a more nuanced and holistic view of young people and their trajectories across the lifecourse in designing policy that will effectively facilitate intergenerational poverty reduction.

\section{Notes}

1 This is true of the broader CCT literature as well.

2 The Bolsa Escola ('School grant') constituted the education-related conditional cash transfer that was later integrated into the Bolsa Família programme.

3 This is further evidenced by the age requirements for young people to receive the benefit, which are limited to the age range for completion of the basic education cycle, based on a linear, uninterrupted progression.

4 This linear movement from schooling and towards the labour market, and the notion that young people should enter the labour market only after the completion of the basic education cycle, is at the heart of CCTs and the BFP. The cash benefit is conceived as compensation for the opportunity cost of young people's labour (which they are assumed to give up in favour of attending formal schooling). Moreover, one of the predecessors to the BFP was the Programa de Erradicação do Trabalho Infantil (Programme for the Elimination of Child Labour) which had a specific mandate of removing children from the labour market, thus establishing a clear dichotomy between work and school in children's lives, in line with a 'life stages' model of development.

\section{References}

Almeida, M. da C. Chagas de and Aquino, E. M. L. (2009) 'The role of education level in the intergenerational pattern of adolescent pregnancy in Brazil', International Perspectives on Sexual and Reproductive Health, 35, 3, 139-46.

Arabsheibani, G. R., Carneiro, F. G. and Henley, A. (2006) 'Changes in human capital and earnings inequality: recent evidence from Brazil', Journal of Development Studies, 42, 5, 837-67. 
Arbache, J. S. and Loureiro, P. R. A. (2012) 'The effect of a change in legislation on the wage gap in Brazil', International Journal of Economics and Finance, 4, 2, 94-102.

Arcand, J.-L. and D'Hombres, B. (2004) 'Racial discrimination in the Brazilian labour market: wage, employment and segregation effects', Journal of International Development, 16, 8, 1053-66.

Arias, O., Yamada, G. and Tejerina, L. (2004) 'Education, family background and racial earnings inequality in Brazil', International Journal of Manpower, 25, 3/4, 355-74.

Barrientos, A. and Nino-Zarazua, M. (2011) Social Transfers and Chronic Poverty: Objectives, Design, Reach and Impact, Manchester: Chronic Poverty Research Centre, University of Manchester.

Becker, G. S. (1962) 'Investment in human capital: a theoretical analysis', Journal of Political Economy, $70,5,9-49$.

Becker, G. S. and Chiswick, B. R. (1966) 'Education and the distribution of earnings', American Economic Review, 56, 1/2, 358-69.

Bourguignon, F., Ferreira, F. H. G. and Leite, P. G. (2002) Ex-ante Evaluation of Conditional Cash Transfer Programs: The Case of Bolsa Escola, Washington, DC: The World Bank.

Bourguignon, F., Ferreira, F. H. G. and Leite, P. G. (2003) 'Conditional cash transfers, schooling, and child labor: micro-simulating Brazil's Bolsa Escola program', World Bank Economic Review, 17, 2, $229-54$.

Boyden, J. and Dercon, S. (2012) Child Development and Economic Development: Lessons and Future Challenges, Young Lives, Oxford: University of Oxford.

Bruns, B., Evans, D. and Luque, J. (2012) Achieving World-Class Education in Brazil: The Next Agenda, Washington, DC: The World Bank.

Cacciamali, M. C. and Tatei, F. (2013) 'Género y Salarios de la Fuerza de Trabajo Calificada en Brasil y México', Problemas del Desarollo, 44, 172, 53-79.

Camfield, L. (2011) 'Young lives in transition: from school to adulthood?' [Editorial], European Journal of Development Research, 23, 669-78.

CEDEPLAR (2005) Avaliação de Impacto do Programa Bolsa Família, Belo Horizonte, Brazil: Universidade Federal de Minas Gerais.

CEPAL (2012) Eslabones de la Desigualdad: Hetergeneidad estructural, empleo y protección social, Comisión Económica para América Latina y el Caribe.

CREATE (2008) Reconceptualising Access to Education, Consortium for Research on Education, Access, Transitions and Equity, University of Sussex, Brighton, UK.

Collins, R. (1971) 'Functional and conflict theories of educational stratification', American Sociological Review, 36, 6, 1002-19.

Collins, R. (1979) The Credential Society: An Historical Sociology of Education and Stratification, New York: Academic Press.

Davis, K. and Moore, W. E. (1945) 'Some principles of stratification', American Sociological Review, 10, 2, 242-9.

Digilova, A., Boy, V. A., Muthalaly, R., Ziauddin, I. K. and Menn, U. (2014) 'A comprehensive appraoch to conditional cash transfers', Georgetown Journal on Poverty Law and Policy, 22, 1, 1-31.

Ferreira, S. G. and Veloso, F. A. (2006) 'Intergenerational mobility of wages in Brazil', Brazilian Review of Econometrics, 26, 2, 181-211.

Fiszbein, A. and Schady, N. (2009) Conditional Cash Transfers: Reducing Present and Future Poverty, Washington, DC: The World Bank.

Fontes, A., Pero, V. and Berg, J. (2012) 'Low-paid employment in Brazil', International Labour Review, 151, 3, 193-219

Giovannetti, B. and Menezes-Filho, N. (2006) 'Trade liberalization and the demand for skilled labor in Brazil', Economia: Journal of the Latin American and Caribbean Economic Association, 7, 1, 1-20.

Glewwe, P. and Kassouf, A. L. (2012) 'The impact of the Bolsa Escola/Família conditional cash transfer program on enrollment, grade promotion and drop out rates in Brazil', Journal of Development Economics, 97, 2, 505-17.

Granovetter, M. (1974) Getting a Job: A Study of Contacts and Careers, Chicago, IL: University of Chicago Press. 
Hanushek, E. (2009) 'School policy: implications of recent research for human capital investments in South Asia and other developing countries', Education Economics, 17, 3, 291-313.

Harper, C. and Marcus, R. (2003) 'Enduring poverty and the conditions of childhood: lifecourse and intergenerational poverty transmissions', World Development, 31, 3, 535-54.

Jeffery, C. (2010) 'Geographies of children and youth I: eroding maps of life', Progress in Human Geography, 34, 4, 496-505.

Jeffrey, C. (2011) 'Youth and development [commentary]', European Journal of Development Research, 23, 792-6.

Jeffery, C. and Dyson, J. (eds.) (2008) Telling Young Lives: Portraits of Global Youth, Philadelphia, PA: Temple University Press.

Jeffrey, C. and McDowell, L. (2004) 'Youth in comparative perspective: global change, local lives', Youth and Society, 36, 2, 131-42.

Küpfer, D., Castilho, M., Dweck, E. and Nicoll, M. (2012) Diferentes parceiros, diferentes padrões: Comércio e mercado de trabalho do Brasil nos anos 2000, Santiago, Chile: Comisión Económica para América Latina y el Caribe.

Leu, E. (2005) The Role of Teachers, Schools, and Communities in Quality Education: A Review of the Literature, AED Working Paper, Washington, DC: Academy for Educational Development, Global Education Centre.

Lin, N. (1999) 'Social networks and status attainment', Annual Review of Sociology, 25, 1, 467-87.

Lindert, K., Linder, A., Hobbs, J. and de la Brière, B. (2007) The Nuts and Bolts of Brazil's Bolsa Família Program: Implementing Conditional Cash Transfers in a Decentralized Context, Social Protection Discussion Paper No. 0709, Washington, DC: The World Bank.

Lomelí, E. V. (2008) 'Conditional cash transfers as social policy in Latin America: an assessment of their contributions and limitations', Annual Review of Sociology, 34, 475-99.

Loureiro, P., Galrão Carneiro, F. and Sachsida, A. (2004) 'Race and gender discrimination in the labor market: an urban and rural sector analysis for Brazil', Journal of Economic Studies, 31, 2, 129-43.

Lovell, P. A. (2003) 'Race, gender and regional labor market inequalities in Brazil', in W. A. Darity and A. Deshpande (eds.), Boundaries of Clan and Color: Transnational Comparisons of Inter-Group Disparity, New York: Routledge, pp. 14-26.

Lovell, P. A. (2006) 'Race, gender, and work in São Paulo, Brazil, 1960-2000', Latin American Research Review, 41, 3, 63-87.

Manacorda, M., Sanchez- Paramo, C. and Schady, N. (2010) 'Changes in returns to education in Latin America: the role of demand and supply of skills', Industrial and Labor Relations Review, 63, 2, 307-26.

Marió, E. G., Woolcock, M. and von Bulow, M. (2008) 'Assessing social exclusion and mobility in Brazil', in E. G. Marió and M. Woolcock (eds.), Social Exclusion and Mobility in Brazil, Brasilia, Brazil: IPEA/World Bank.

Marshall, C. and Hill, P. S. (2015) 'Ten best resources on conditional cash transfers', Health Policy and Planning, 30, 742-6.

MDS (2015) Bolsa Família: Benefícios, http://mds.gov.br/assuntos/bolsa-familia/o-que-e/beneficios/ beneficios [accessed 20.10. 2015].

Menezes-Filho, N. and Scorzafave, L. (2009) Employment and Inequality of Outcomes in Brazil, Insper Working Paper, São Paulo, Brazil: Insper Instituto de Ensino e Pesquisa.

Mincer, J. (1958) 'Investment in human capital and personal income distribution', Journal of Political Economy, 66, 4, 281-302.

Moore, K. (2005) Thinking About Youth Poverty Through the Lenses of Chronic Poverty, Life-Course Poverty and Intergenerational Poverty, CPRC Working Paper No. 57, Manchester: Chronic Poverty Research Centre, University of Manchester.

Morrow, V. (2013) 'Troubling transitions? Young people's experiences growing up in poverty in rural Andhra Pradesh, India', Journal of Youth Studies, 16, 1, 86-100. 
Mouw, T. (2003) 'Social capital and finding a job: do contacts matter?', American Sociological Review, 68, 6, 868-98.

Organization for Economic Cooperation and Development (OECD) (2010) Brazil: Encouraging Lessons from a Large Federal System, Organization for Economic Cooperation and Development.

Organization for Economic Cooperation and Development (OECD) (2012) Brazil: Country Note - Results from PISA 2012, Organization for Economic Cooperation and Development.

Phelps, E. S. (1972) 'The statistical theory of racism and sexism', The American Economic Review, 62, 4, 659-61.

PREAL (2009) Overcoming Inertia? A Report Card on Education in Brazil, Programa de Promoción de la Reforma Educativa en América Latina y el Caribe and the Lehman Foundation.

Punch, S. (2002) 'Youth transitions and interdependent adult-child relations in rural Bolivia', Journal of Rural Studies, 18, 2, 123-33.

Resende, A. C. C. and Oliveira, A. M. H. C. de (2008) 'Avaliando resultados de um programa de transferência de renda: O impacto do Bolsa-Escola sobre os gastos das famílias brasileiras', Estudos Econômicos São Paulo, 38, 2, 235-65.

Roelen, K. (2014) 'Challenging assumptions and managing expectations: moving towards inclusive social protection in southeast Asia', Journal of Southeast Asian Economies, 31, 1, 57-67.

Saad-Filho, A. (2015) 'Social policy for neoliberalism: the Bolsa Família programme in Brazil', Development and Change, 46, 6, 1227-52.

Saboia, A. and Saboia, J. (2009) 'Whites, blacks, and brown in the labor market in Brazil: a study about inequalities', Review of Black Political Economy, 36, 2, 127-35.

Santarrosa, R. B. (2011) 'Impacto das transferências condicionadas de renda sobre a proficiência dos alunos do ensino fundamental no Brasil', Master's Thesis. Fundação Getúlio Vargas, Escola de Economia de São Paulo, São Paulo, Brazil.

Silveira Neto, R. da M. (2010) 'Impacto do Programa Bolsa Família sobre a freqüência à escola: Estimativas a partir de informações da Pesquisa Nacional por Amostra de Domicílio (PNAD)', in J. Abrahão de Castro and L. Modesto (eds.), Bolsa Família 2003-2010: Avanços e Desafios, Brasilia, Brazil: Instituto de Pesquisa Econômica Aplicada (IPEA).

Soares, S. (2012) Bolsa Família, Its Design, Its Impacts and Possibilities for the Future, Working Paper No. 89, Brasilia, Brazil: International Centre for Inclusive Growth.

Soares, F. V., Ribas, R. P. and Osório, R. G. (2010) 'Evaluating the impact of Brazil's Bolsa Família: conditional cash transfers in perspective', Latin American Research Review, 45, 2, 173-90.

Tawil, S., Akkari, A. and Macedo, B. (2012) Beyond the Conceptual Maze: The Notion of Quality in Education, Occasional Paper, Paris: UNESCO.

Thompson, R. (2002) 'Critical moments: choice, chance and opportunity in young people's narratives of transition', Sociology, 36, 2, 335-54.

Vigh, H. (2009) 'Motion squared: a second look at the concept of social navigation', Anthropological Theory, 9, 2, 419-38.

World Bank (2015) Adolescent Fertility Rate, http://data.worldbank.org/indicator/SP.ADO.TFRT/countries [accessed 29.09.2015].

Wyn, J. and Dwyer, P. (2000) 'New patterns of youth transition in education', International Social Science Journal, 52, 164, 147-59.

Zepeda, E., Alarcon, D., Soares, F. V. and Osório, R. G. (2009) 'Changes in earnings in Brazil, Chile and Mexico: disentangling the forces behind pro-poor change in labour markets', Working Paper No. 51, Brasilia, Brazil: International Policy Centre for Inclusive Growth. 